\title{
Cannabidiol Signaling in the Eye and Its Potential as an Ocular Therapeutic Agent
}

\author{
Alyssa Aebersold Max Duff Lucy Sloan Zhao-Hui Song \\ Department of Pharmacology and Toxicology, University of Louisville School of Medicine, Louisville, \\ Kentucky, USA
}

\section{Key Words}

Cannabidiol - Molecular target - Mechanism of action - Therapeutic potential • Ocular pharmacology

\begin{abstract}
Cannabidiol (CBD), the major non-intoxicating constituent of Cannabis sativa, has gained recent attention due to its putative therapeutic uses for a wide variety of diseases. CBD was discovered in the 1940s and its structure fully characterized in the 1960s. However, for many years most research efforts related to cannabis derived chemicals have focused on $\Delta^{9}$-tetrahydrocannabinol (THC). In contrast to THC, the lack of intoxicating psychoactivity associated with CBD highlights the potential of this cannabinoid for clinical drug development. This review details in vitro and in vivo studies of CBD related to the eye, the therapeutic potential of cannabidiol for various ocular conditions, and molecular targets and mechanisms for CBD-induced ocular effects. In addition, challenges of CBD applications for clinical ocular therapeutics and future directions are discussed.
\end{abstract}

\section{Introduction}

\section{A brief history of cannabis}

Cannabis sativa is a plant species that includes both cannabis and hemp. It first appeared in Chinese medical texts around 2000 years ago [1]. Records from Britain indicate that cannabis was brought from Egypt by Napoleon's troops in the early 1800s [2]. Shortly thereafter, hemp was introduced to Western medicine when in 1840, a hemp tincture from ground plant matter was reported to be an effective treatment for convulsive disorders and tetanus [3]. By 1851, a cannabis extract was included in the $3^{\text {rd }}$ edition of the Unites States Pharmacopoeia and readily available in American pharmacies [4, 5].

In 1913, however, cannabis was made illegal in California due to a wide-spread antinarcotics campaign [5]. Cannabis became federally illegal when Harry Anslinger from California introduced the Marijuana Tax Act of 1937 banning the sale and use of cannabis

A. Aebersold and M. Duff contributed equally to this work. 
nationally $[5,6]$. A negative stigma continued to develop in the US around cannabis, then associated with narcotics, that culminated with the Controlled Substances Act (CSA) of 1970, which classified cannabis and cannabinoids as Schedule I with no recognized medical use [7]. Recently, America is witnessing a revival in the popularity of cannabis, both medically and recreationally. In 1996, California was the first state to legalize cannabis for medical use and more states have followed California in recent years [8]. To date, 16 states and Washington D.C. have legalized both medical and recreational cannabis with an additional 26 states legalizing medical cannabis at varying degrees. Moreover, the Agricultural Acts of 2014 and 2018 removed hemp from the list of controlled substances and redefined industrial hemp as cannabis containing less than $0.3 \%$ THC $[9,10]$. As a result of the recent wave of recreational and medical cannabis legalization, in conjunction with the end to the prohibition of hemp, cannabis research is quickly expanding.

\section{Cannabidiol}

Cannabidiol (CBD) is one of over 120 chemicals produced by the Cannabis sativa plant termed phytocannabinoids $[11,12]$. There are potentially more, as 21 previously unknown cannabinoids were recently identified [13]. The two most abundant phytocannabinoids in cannabis are psychoactive and intoxicating $\Delta^{9}$-tetrahydrocannabinol (THC) and nonintoxicating CBD.

CBD was first isolated in the 1940 and its structure and stereochemistry fully determined in 1963 [14, 15]. CBD and THC are both derived from cannabigerolic acid [16]. Although the structure of CBD was discovered before THC $[15,17]$, THC had been the major focus of research related to cannabis and cannabinoids. This focus is driven, in part, by the activity of THC at the canonical cannabinoid receptors, CB1 and CB2. However, there are many targets for cannabinoids other than CB1 and CB2. For example, CBD has upwards of 65 known targets consisting of receptors, enzymes, ion channels and transient receptor potential (TRP) channels [18].

\section{Cannabinoids in pharmaceuticals}

Cannabinoid containing drugs are approved for medical use in the USA and other countries. The drugs differ in their formulation and indicated uses. Dronabinol (Marinol) was the first cannabinoid-containing medicine approved by the FDA in 1985. It is a soft gel capsule containing synthetic THC [19]. Syndros is an oral solution of dronabinol [20]. Cesamet (nabilone) is the third synthetic cannabinoid drug approved by the FDA in May of 2006 [21]. All three are prescribed for anorexia associated with weight loss in AIDS patients and nausea/vomiting in cancer patients [19-22]. While plant-derived THC is a Schedule I substance, Marinol is listed under Schedule III and Cesamet and Syndros are controlled under Schedule II [19-21].

Epidiolex is an oil formulation of CBD approved by the FDA in June of 2018 for treatment of Lennox-Gastaut syndrome and Dravet syndrome, two rare and severe forms of pediatric epilepsy [23]. In July of 2020, it was approved for treating seizures in a rare genetic disease, tuberous sclerosis complex (TSC) [24]. Epidiolex is the only FDA approved drug containing a compound directly derived from cannabis. It was originally classified as schedule $\mathrm{V}$, but is no longer a controlled substance as the FDA deemed it safe and effective for treatment of the aforementioned conditions [25]. Sativex is a 1:1 alcohol solution of THC and CBD administered as an oromucosal spray that is approved in 25 countries for the treatment of pain and spasticity in multiple sclerosis patients [26]. Despite its approval in other countries, Sativex is not yet approved by the FDA in the US.

\section{Research on cannabidiol}

CBD, through a variety of mechanisms and targets, has numerous potential therapeutic uses for a plethora of conditions. The assertion of potential therapeutic actions of CBD is based on pre-clinical data, limited clinical data and ongoing human clinical trials. Preclinical studies show that CBD has antioxidant [27, 28] anti-inflammatory [27], anti- 
convulsant [29, 30], neuroprotective [31], and anti-cancer properties [32]. CBD also shows potential as a therapeutic agent in cardiovascular [33], neurological, and neuropsychiatric disorders [26]. The completed clinical trials involve CBD use in epilepsy and seizures disorders (21 trials), general pain and pain associated disorders (19 trials), drug abuse and use disorders ( 14 trials), other neurologic conditions ( 4 trials) and psychiatric conditions (11 trials). In addition, there are currently 85 active clinical trials in the United States containing CBD (including Epidiolex and Sativex) on clinicaltrials.gov.

Over the past two decades, multiple studies have investigated the therapeutic potentials of CBD in the eye. There are several published reviews of cannabinoids for treatment of glaucoma [34, 35], and retinal disorders [36, 37]. Nevertheless, there are currently no reviews that focus solely on CBD for ocular conditions. In this review, we aim to fill the gap in literature with a focus on CBD ocular pharmacology. We will discuss therapeutic potentials of CBD for ocular conditions, ocular molecular targets for CBD, and mechanisms of actions of CBD in the eye.

\section{Results}

\section{Therapeutic potentials of cannabidiol for ocular conditions}

CBD is recognized for its antioxidant, anti-inflammatory and neuroprotective properties. In this section, we discuss the observed effects of CBD in ocular tissues and its indication for ocular disorders. Specifically, we will discuss studies of CBD in corneal inflammation and pain, endotoxin-induced inflammation, excitotoxicity, diabetic retinopathy, and intraocular pressure (Table 1 and Table 2).

\section{Corneal Inflammation and pain}

The cornea is a thin and avascular tissue that is innervated by sensory nerves. When corneal damage occurs due to infection, surgery, or trauma, it can develop into corneal neuropathic pain characterized by hyperalgesia, chronic and debilitating pain, and inflammation $[38,39]$. The inflammatory response to corneal damage leads to the production of proinflammatory cytokines, recruitment of leukocytes, release of pain-producing neuropeptides, and neovascularization (NV) in the cornea [38, 39].

In a recent study, CBD was found to be anti-nociceptive and anti-inflammatory in a mouse model of corneal hyperalgesia [39] (Table 1). Mice with silver nitrate cauterized corneas that treated with CBD showed lower pain scores in capsaicin pain challenges, indicating an antinociceptive effect of CBD. Moreover, CBD treated corneas showed less corneal neutrophil infiltration which is indicative of a CBD-induced anti-inflammatory effect. Lastly, WAY100635, a $5 \mathrm{HT}_{1 \mathrm{~A}}$ antagonist, blocked the effects of CBD, suggesting that the anti-inflammatory and anti-nociceptive effects are likely mediated through activation of the serotonin $5 \mathrm{HT}_{1 \mathrm{~A}}$ receptor [39]. This study highlights CBD as a potential therapeutic for corneal pain and inflammation.

Table 1. Therapeutic potentials of CBD for ocular conditions

\begin{tabular}{|c|c|c|c|c|c|}
\hline Ref. & Disease & Model & CBD route & CBD effect & Therapeutic relevance \\
\hline [39] & $\begin{array}{l}\text { Corneal pain and } \\
\text { inflammation }\end{array}$ & $\begin{array}{l}\text { Silver nitrate } \\
\text { cauterization-induced } \\
\text { corneal hyperalgesia in } \\
\text { mice }\end{array}$ & topical & $\begin{array}{l}\downarrow \text { corneal hyperalgesia } \\
\downarrow \text { neutrophil infiltration }\end{array}$ & $\begin{array}{l}\text { CBD is anti-nociceptive and anti- } \\
\text { inflammatory in the cornea } \\
\text { following corneal surface injury }\end{array}$ \\
\hline$[44]$ & $\begin{array}{l}\text { Retinal } \\
\text { inflammation }\end{array}$ & $\begin{array}{l}\text { Endotoxin-induced } \\
\text { inflammation in rat } \\
\text { retina and primary } \\
\text { retinal microglial cells }\end{array}$ & intraperitoneal & $\begin{array}{l}\downarrow \text { adenosine reuptake } \\
\downarrow \mathrm{TNF} \alpha \text { production }\end{array}$ & $\begin{array}{l}\text { CBD is anti-inflammatory in the } \\
\text { retina via inhibiting adenosine } \\
\text { reuptake }\end{array}$ \\
\hline [51] & $\begin{array}{l}\text { Retinal } \\
\text { neurotoxicity }\end{array}$ & $\begin{array}{l}\text { Intravitreal injection of } \\
\text { NMDA in rats }\end{array}$ & intravenous & $\begin{array}{l}\downarrow \text { nitrotyrosine formation } \\
\downarrow \text { nitrite/nitrate } \\
\downarrow \text { lipid peroxidation } \\
\downarrow \text { apoptosis }\end{array}$ & $\begin{array}{l}\text { CBD is neuroprotective against } \\
\text { retinal excitotoxicity }\end{array}$ \\
\hline$[58]$ & $\begin{array}{l}\text { Diabetic } \\
\text { retinopathy }\end{array}$ & $\begin{array}{l}\text { Streptozotocin- } \\
\text { induced diabetic rats }\end{array}$ & intraperitoneal & $\begin{array}{l}\downarrow \text { TNF } \alpha \text {, ICAM-1, and VEGF expression } \\
\downarrow \text { p38 MAP kinase activation } \\
\downarrow \text { ROS formation }\end{array}$ & $\begin{array}{l}\text { CBD protects retina from diabetes } \\
\text { related inflammation, vascular } \\
\text { permeability, and neurotoxicity }\end{array}$ \\
\hline
\end{tabular}


Table 2. The effects of CBD on intraocular pressure

\begin{tabular}{|c|c|c|c|c|c|c|}
\hline Ref & Species & Route & Dose Frequency & Vehicle & Dose & Effect on IOP \\
\hline [73] & Rabbit & intravenous & 1 application & $2 \%$ Tween 60 and $3 \%$ Arlacel in water & $\begin{array}{l}1 \mathrm{mg} / \mathrm{kg} \\
10 \mathrm{mg} / \mathrm{kg}\end{array}$ & $\begin{array}{l}\text { No change } \\
\text { No change }\end{array}$ \\
\hline [70] & Monkey & Oral & 1 application & $2 \%$ Tween 60 and $3 \%$ Arlacel in water & $10 \mathrm{mg} / \mathrm{kg}$ & No change \\
\hline [71] & Rabbit & intravenous & 1 application & $100 \%$ alcohol & $\begin{array}{l}0.1 \mathrm{mg} / \text { animal } \\
1 \mathrm{mg} / \text { animal } \\
10 \mathrm{mg} / \text { animal }\end{array}$ & $\begin{array}{l}\text { No change } \\
\text { No change } \\
\text { No change }\end{array}$ \\
\hline$[72]$ & Rabbit & intravenous & 1 application & $25 \% \mathrm{BSA}$ in $95 \% \mathrm{EtOH}$ & $1 \mathrm{mg} /$ animal & No change \\
\hline \multirow[t]{2}{*}{ [75] } & \multirow[t]{2}{*}{ Rabbit } & \multirow[t]{2}{*}{ Topical } & \multirow[t]{2}{*}{1 application } & Mineral oil & $\begin{array}{l}0.0001 \% \\
0.001 \% \\
0.01 \% \\
0.1 \% \\
1 \%\end{array}$ & $\begin{array}{l}\downarrow \\
\downarrow \\
\downarrow \\
\downarrow \\
\downarrow\end{array}$ \\
\hline & & & & Sesame oil & $0.1 \%$ & No change \\
\hline [74] & Human & intravenous & 1 application & $25 \%$ human serum albumin & $20 \mathrm{mg} /$ person & $\downarrow$ \\
\hline [76] & Cats & $\begin{array}{l}\text { Topical via } \\
\text { minipump }\end{array}$ & $\begin{array}{l}\text { Continuously for } \\
9 \text { days }\end{array}$ & Polyethylene glycol & $20 \mathrm{mg} /$ hour & $\downarrow$ \\
\hline [64] & Human & Sublingual & $\begin{array}{l}4 \text { spray at } 5- \\
\text { minute intervals }\end{array}$ & $\begin{array}{l}\text { Oromucosal spray } \\
\text { with non-specified vehicle }\end{array}$ & $\begin{array}{l}20 \mathrm{mg} \\
40 \mathrm{mg}\end{array}$ & $\begin{array}{l}\text { No change } \\
\text { Transient } \uparrow\end{array}$ \\
\hline \multirow[t]{2}{*}{ [63] } & $\begin{array}{l}\text { Wild type } \\
\text { C57/B6 Mice }\end{array}$ & topical & 1 application & Tocrisolve, a soya-based solvent & $5 \mathrm{mM}$ & $\uparrow$ at 1 and 4 hours \\
\hline & CB1 knockout mice & & & & $5 \mathrm{mM}$ & $\downarrow$ at 1 hour \\
\hline
\end{tabular}

\section{Endotoxin-induced inflammation}

The mammalian retina contains three distinct glia cells types: Müller cells, astrocytes, and microglia. Microglial cells are the resident macrophages of the retina and play important roles in retinal homeostasis [40]. Activation of microglial cells induces the release of proinflammatory cytokines, such as IL- $1 \beta$ and $\mathrm{TNF} \alpha$, instigating an inflammatory response. Prolonged microglial activation and chronic inflammation contribute to disease pathology and retinal degeneration [40].

The degree of microglial activation may relate to the severity of injury. In vitro and in vivo treatment with lipopolysaccharide (LPS), an endotoxin from bacteria, is used to study inflammation through activated microglia [41]. Extracellular adenosine can function as an endogenous anti-inflammatory agent suppressing immune cell responses. For example, adenosine inhibits pro-inflammatory cytokine expression such as TNF $\alpha$ [42]. However, the anti-inflammatory effects of adenosine are short, as it is rapidly taken up by adjacent cells. Inhibitors of adenosine uptake may enhance the adenosine signaling and endogenous activity [43]. CBD has been shown to decrease TNF $\alpha$ expression and inhibit equilibrative nucleoside transporter 1 (ENT1) reuptake of adenosine in LPS treated primary microglia cells and retinas from LPS treated rats [44] (Table 1). The effect of CBD is primarily mediated through the activation of the $A_{2 A}$ receptor, the most abundant adenosine receptor in the rat retina, as a result of CBD-induced inhibition of adenosine reuptake [44]. These results suggest that CBD may be a good anti-inflammatory agent for endotoxin-induced retinal damage.

\section{Excitotoxicity}

Excitotoxicity is implicated in glaucoma as a result of elevated levels of the excitatory neurotransmitter glutamate in the retina $[45,46]$. Over-stimulation of a glutamate receptor, such as the N-methyl-D-aspartate (NMDA) receptor, a sodium and calcium permeable channel, results in excess intracellular calcium. Increased intracellular calcium is cytotoxic, as well as induces release of more glutamate, cellular swelling, and eventually cell death [47, 48]. The process of excitotoxicity also involves the activation of nitric oxide (NO) synthase and accumulation of $\mathrm{NO}$ and superoxide. Overproduction of these oxygen species produces oxidative stress leading to lipid peroxidation, mitochondrial dysfunction, DNA damage and eventually, cell death $[46,49]$.

One method to measure oxidative stress is through peroxynitrite/nitrotyrosine formation and lipid peroxidation [50]. Peroxynitrite is a product of a superoxide reaction primarily responsible for oxide- and superoxide-dependent cytotoxicity. It is highly unstable, highly reactive and difficult to measure, therefore the presence of peroxynitrite is measured by levels of nitrotyrosine which is formed by nitration of protein-bound tyrosine [50]. 
In a rat model of neurotoxicity, intravitreal injection of NMDA induces nitrite/ nitrate accumulation, lipid peroxidation, nitrotyrosine production, apoptosis, and inner retinal neuronal loss [51]. CBD treatment decreased levels of peroxynitrite/nitrotyrosine production, prevented neurotoxicity, and lowered the amount of apoptosis (Table 1). The neuroprotective effect of CBD was dependent upon blockage of nitrotyrosine formation [51]. The retinal antioxidant and neuroprotective effects of CBD in the rat model of retinal excitotoxicity suggest that it may be beneficial as a neuroprotectant for the treatment of ocular conditions such as glaucoma.

\section{Diabetic retinopathy}

Globally, diabetic retinopathy is a major cause of vision loss. Oxidative stress, caused by reactive oxygen species, is one of the main factors in diabetic retinopathy progression [52]. The retina is particularly sensitive to reactive oxygen species because it is the most metabolically active tissue in the body and therefore easily affected by diabetes [52]. Diabetic retinopathy is characterized by retinal hypoxia, increased retinal vascular permeability, and retinal angiogenesis $[52,53]$. These processes cause the death of inner retinal and ganglion cells and ultimately, vision loss.

Inflammation is another important component in diabetic retinopathy. Hyperglycemia triggers the release of proinflammatory cytokines such as vascular endothelial growth factor (VEGF), Intercellular adhesion molecule-1 (ICAM-1), and Tumor necrosis factor $\alpha$ (TNF $\alpha$ ) $[54,55]$. The elevation of these proinflammatory cytokines further facilitates pathologic changes in diabetic retinopathy as a result of neovascularization by VEGF, leukocyte adhesion and transmigration by ICAM- 1 and further release of cytokines by TNF $\alpha$ [53-55]. Research shows that VEGF, ICAM-1, and TNF $\alpha$ are upstream regulators of proinflammatory and oxidative stress pathways which activate p38 MAP kinase [55]. Activation of p38 MAP kinase has been reported in diabetic retinas in high glucose conditions and is implicated in retinal ganglion cell apoptotic death [56-58]. In addition, p38 MAP kinase activity is linked to vascular hyperpermeability in diabetic retinas [55].

One report assessed the therapeutic potential of CBD in a streptozotocin-induced diabetic rat model through measurement of oxidative stress and proinflammatory cytokines [58] (Table 1). The antibiotic streptozotocin (produced by Streptomyces achromogens) induces type 1 diabetes through partial destruction of the pancreatic $\beta$ cells after a single injection. In the streptozotocin-induced diabetic rat model there were increases in oxidative stress, retinal neuronal cell death, and vascular hyperpermeability associated with increased levels of VEGF, ICAM-1, TNF $\alpha$, and activation of p38 MAP kinase [58]. Importantly, CBD decreased reactive oxygen species (ROS) formation, suppressed VEGF, ICAM-1, and TNF- $\alpha$ expression, and prevented activation of p38 MAP kinase [58]. Taken together, these findings suggest that CBD is a potential therapeutic agent for diabetic retinopathy capable of protecting against inflammation, retinal neuronal cell death, and preservation of the blood-retinal barrier.

\section{Intraocular pressure}

An estimated 3 million Americans have glaucoma, a major cause of irreversible blindness with no cure $[59,60]$. Even with therapeutic intervention, approximately $10 \%$ of those diagnosed still experience vision loss $[59,60]$. Although not always elevated, intraocular pressure (IOP) is currently the only treatable factor of the disease. Drug therapies such as prostaglandin analogs, $\beta$-adrenergic antagonists, cholinergic agonists, $\alpha_{2}$-adrenergic agonists, and carbonic anhydrase inhibitors are used either independently or in combination, to reduce ocular pressure $[61,62]$. In 2018, the FDA approved Rhopressa, a Rho kinase inhibitor, as a novel IOP-lowering drug [61, 62]. These IOP-lowering drugs work to decrease aqueous humor production in the ciliary body and/or increase aqueous humor drainage through the trabecular meshwork or the uveoscleral pathway $[61,62]$. For patients that do not respond to the above drugs or drug combinations, or patients developed tolerance to existing drugs, novel medications are needed to lower IOP and to prevent future optic nerve damage and vision loss associated with glaucoma. 
THC is well documented and is consistently shown to decrease IOP [63-69]. However, the effect of CBD on IOP is much more controversial (Table 2). So far, nine independent reports have published regarding the effects of CBD on IOP: Four reports indicate that CBD has no effect on IOP [70-73], three reports demonstrate that CBD decreases IOP [74-76], and two reports show an CBD-induced increase in IOP $[63,64]$.

A recently published study in mice showed an increase in IOP at 1 and 4 hours post topical application of CBD at a $5 \mathrm{mM}$ dose [63]. Interestingly, CBD significantly decreased IOP 1 hour post treatment in CB1 knockout mice and the effect is attributed to GPR18 activation [63]. This article was cited by the American academy of ophthalmology with the headline "CBD oil may worsen glaucoma" [77]. Altogether, the literature does not conclusively show whether CBD increases, decreases, or causes no change to IOP.

\section{Molecular targets and mechanisms for CBD-induced ocular effects}

CBD has numerous targets in different categories such as $\mathrm{G}$ protein-coupled receptors, enzymes, nuclear receptors, ligand-gated ion channels, transient receptor potential (TRP) channels, and potentially others [18]. Many of these CBD targets are expressed in the eye. This section of the review focuses on the effects of CBD on these molecular targets in the eye (Table 3). It is important to point out that systemic CBD administration may result in CBD metabolites that act through molecular mechanisms different from those of CBD itself.

\section{Serotonin receptor}

Thapa et al. showed that CBD can reduce the pain score and neutrophil infiltration in mice after corneal cauterization and capsaicin challenge and this effect is mediated, in part, by 5-HT ${ }_{1 \mathrm{~A}}$ agonism [39] (Table 3). The hypoalgesic and anti-inflammatory effects of CBD seen in wild-type mice were still present in CB2 knockout mice, as well as CB2 knockout mice pretreated with AM251, a CB1 selective antagonist. These results suggest that the hypoalgesic and anti-inflammatory effects of CBD are not mediated by CB1 or CB2 receptors. Moreover, the effects of CBD were blocked in wild-type mice treated with WAY100635, a $5-\mathrm{HT}_{1 \mathrm{~A}}$ receptor antagonist. These data demonstrate that the effect of CBD on corneal hyperalgesia inflammation is mediated by $5-\mathrm{HT}_{1 \mathrm{~A}}$ agonism [39]. In support of the findings of Thapa et al. in the eye [39], CBD has been shown to be a 5-HT $\mathrm{HA}_{1 \mathrm{~A}}$ agonist in other tissues as well $[78,79]$.

\section{Equilibrative nucleoside transporter 1 and $A_{2 A}$ adenosine receptor}

CBD has been shown to inhibit TNF- $\alpha$ response to LPS stimulation by inhibiting adenosine reuptake in retinal microglia via adenosine equilibrative nucleoside transporter 1 (ENT1) [44] (Table 3). Cells that were pre-treated with CBD showed inhibition of LPS-induced release of TNF- $\alpha$. The inhibition of TNF- $\alpha$ release was not further enhanced nor inhibited by pretreatment of NBMPR, an ENT1 selective inhibitor [44]. These results suggest that CBD

Table 3. Molecular targets and mechanisms for CBD-induced ocular effects

\begin{tabular}{|c|c|c|c|c|c|}
\hline Ref & Target & Tissue/ Cells & CBD route & CBD effect & CBD mechanism \\
\hline [39] & $5-\mathrm{HT}_{1 \mathrm{~A}}$ & Mouse cornea & topical & $\begin{array}{l}\downarrow \text { pain score } \\
\downarrow \text { neutrophil infiltration }\end{array}$ & $\begin{array}{l}\text { 5-HT } 1 \mathrm{~A} \text { agonist, } \\
\text { effect blocked by } 5-\mathrm{HT}_{1 \mathrm{~A}} \text { antagonist WAY100635 }\end{array}$ \\
\hline [44] & $\begin{array}{l}\text { ENT1 } \\
\text { A } 2 \mathrm{~A}^{-1}\end{array}$ & Rat retinal microglia & intraperitoneal & $\begin{array}{l}\downarrow \text { adenosine reuptake } \\
\downarrow \text { TNF } \alpha \text { expression }\end{array}$ & $\begin{array}{l}\text { ENT1 inhibitor, } \\
\text { reuptake inhibition blocked by ENT1 inhibitor NBMPR } \\
\text { Activate } A_{2 A} \text { indirectly, } \\
\text { effect blocked by } A_{2 A} \text { antagonist ZM2 } 41385\end{array}$ \\
\hline [63] & $\begin{array}{l}\text { GPR18 } \\
\text { CB1 }\end{array}$ & $\begin{array}{l}\text { Wild-type and CB1 } \\
\text { knockout mice }\end{array}$ & topical & $\begin{array}{l}\uparrow \text { IOP in wild-type mice } \\
\downarrow \text { IOP in CB1 knockout mice }\end{array}$ & $\begin{array}{l}\text { CB1 negative allosteric modulator } \\
\text { GPR18 agonist, } \\
\text { effect blocked by GPR18 antagonist } 01918\end{array}$ \\
\hline [92] & GPR55 & $\begin{array}{l}\text { Mouse retinal explant } \\
\text { cultures }\end{array}$ & intravitreal & $\begin{array}{l}\downarrow \text { growth cone size } \\
\downarrow \text { filopodia number } \\
\uparrow \text { chemorepulsion }\end{array}$ & $\begin{array}{l}\text { GPR55 antagonist, } \\
\text { effects absent in GPR55 knockout mice }\end{array}$ \\
\hline [98] & TRPV2 & Porcine RPE cells & In vitro & $\uparrow$ intracellular $\mathrm{Ca}^{2+}$ & $\begin{array}{l}\text { TRPV2 agonist, } \\
\text { effect reduced by TRPV2 blocker SKF-96365 }\end{array}$ \\
\hline [99] & TRPV2 & ARPE-19 cells & In vitro & $\begin{array}{l}\uparrow \text { current density } \\
\uparrow \text { membrane conductance }\end{array}$ & $\begin{array}{l}\text { TRPV2 agonist, } \\
\text { effect blocked by TRPV2 blocker SKF- } 96365\end{array}$ \\
\hline
\end{tabular}


competes with NBMPR for ENT1. Furthermore, CBD inhibited TNF- $\alpha$ in the presence of $A_{1 A}$ adenosine antagonist CPX, whereas the effect of CBD was blocked by pre-treatment with $A_{2 A}$ adenosine receptor antagonist ZM241385. When CBD and adenosine were co-administered, TNF- $\alpha$ release was greatly reduced showing a synergistic effect that is greater than when either compound was administered alone [44]. In sum, Liou et al. showed that CBD inhibits adenosine reuptake through ENT1, which indirectly causes the enhanced activation of $A_{2 A}$ adenosine receptor and reduction of TNF- $\alpha$ release [44]. The effects of CBD on ENT1 and adenosine receptors are corroborated by reports in rat and mouse striatal terminals [80] and in EOC-20 murine microglial cells [81].

\section{CB1 and GPR18}

CB1 is a well-established cannabinoid receptor and CBD has been shown to be a negative allosteric modulator of CB1 [82]. CB1 is expressed in the anterior of the eye in the ciliary and corneal epithelium and trabecular meshwork, as well as the posterior of the eye in the retina $[83,84]$. GPR18 is a recently identified putative cannabinoid receptor and researchers have shown that GPR18 is activated by N-arachidonoyl glycine, a carboxylic metabolite of the endocannabinoid anandamide [85]. GPR18 was further characterized in 2012 when anandamide and THC, in addition to N-arachidonoyl glycine, were shown to stimulate GPR18-mediated ERK1/2 phosphorylation [86]. Furthermore, CBD was shown to be a biased agonist for GPR18 in 2014 [87]. GPR18 is widely expressed in the ocular tissues, specifically in the ciliary and corneal epithelium, trabecular meshwork, and retina $[88,89]$.

To date a single paper has reported on the effect of CBD at both CB1 and GPR18 receptors in the eye (Table 3). Miller et al. showed that CBD increases IOP in wild-type mice but decreases IOP in CB1 knockout mice [63]. No CBD effect on IOP was seen in CB1 knockout mice pretreated with 0-1918, a GPR18 antagonist. This report highlights that CBD has independent actions both on CB1 as a negative allosteric modulator to raise IOP and on GPR18 as an agonist to lower IOP [63].

\section{GPR55}

GPR55 is an orphan receptor activated by lysophosphatidylinositol (LPI) [90]. GPR55 is frequently referred to as a putative cannabinoid receptor because it is activated by phytocannabinoids, endocannabinoids, and synthetic cannabinoids [91]. CBD has been shown to be a GPR55 antagonist [91].

One group studied the involvement of GPR55 in the retina during development [92]. Growth cones are regions of developing neurites which facilitate axon growth by extending actin filaments into filopodia. Filopodia guide the growth cone in response to chemical or electrical stimulus. Cherif et al. found that GPR55 is expressed in growth cones during development, and its activity regulates morphology and growth [92]. Mouse embryonic neurons from GPR55 knockout mice showed smaller growth cones, fewer filopodia, and decreased outgrowth compared to neurons from wild type mice. Furthermore, retinal ganglion cells from wild type mice treated with GPR55 agonists LPI and 0-1602 showed increased growth cone size and filopodia number and demonstrated chemoattraction. In contrast, CBD, a GPR55 antagonist, decreased growth cone size and filopodia number, and induced chemorepulsion (Table 3). GPR55 ligands had no effects in embryonic neurons from GPR55 knockout mice [92]. These data suggest that CBD inhibits growth cone activity and axonal growth in the retinain this experimental model.

\section{TRPV Channels}

Transient receptor potential (TRP) ion channels are trans-membrane proteins involved in a wide range of chemical and physical sensations including smell, taste, vision, temperature, and pressure [93]. CBD has been shown to be an agonist of TRPV 1, 2, 3, 4 and TRPA1 [94, 95]. TRPV channels are implicated in the activation and desensitization of inflammatory processes and chronic pain $[96,97]$. Therefore, CBD may be a desirable therapeutic for chronic pain because it can activate and desensitize the TRPV channels [94, 95]. 
One group investigated the calcium influx activity of TRPV2 channel activity in porcine retinal pigment epithelial (RPE) cells [98]. They found that CBD strongly increased intracellular $\mathrm{Ca}^{2+}$ levels (Table 3). In the presence of TRPV2 channel inhibitor SKF96365, CBD-mediated $\mathrm{Ca}^{2+}$ intracellular increase was partially blocked [98]. These data suggest that CBD modulation of $\mathrm{Ca}^{2+}$ involves TRPV2, as well as other TRPV channels that are not blocked by SKF96365.

Another study looked at TRPV2 channel regulation in ARPE-19, a human RPE cell line [99]. ARPE-19 cells preincubated with CBD demonstrated a 3-fold increase in current density, an effect that was blocked by SKF96365 (Table 3). CBD also increased membrane conductance and TRPV2 surface expression. TRPV2 are heat sensitive ion channels and heat further increased the CBD mediated increase in membrane conductance. Furthermore, the PI3 kinase inhibitor LY294002 abolished the effect of CBD on membrane conductance and surface expression. These data led to the conclusion that CBD acts through activation of TRPV2 and a PI3 kinase dependent pathway to increase cell surface expression of TRPV2 channels [99].

\section{Discussion}

Challenges of using CBD as an ocular therapeutic agent

There are several challenges for practical applications of CBD as an ocular therapeutic agent. Some of these challenges include poor bioavailability, difficulty in topical delivery, and short duration of action.

\section{Bioavailability}

An FDA approved drug containing CBD is administered orally [23]. However, oral administration is inefficient due to poor bioavailability of CBD. Low bioavailability of CBD requires that it to be administered at high doses to achieve therapeutic effects. However, a consequence of high dosing is an increase in adverse side effects $[100,101]$. The potential adverse effects of CBD include drowsiness, dry mouth, reduced appetite, nausea, and gastrointestinal issues. The most notable serious adverse side effects of CBD are abnormal liver function tests (elevated liver enzymes) [102].

One major factor contributing to the poor bioavailability of CBD is its extensive first pass metabolism $[100,101]$. Another factor limiting CBD bioavailability is its hydrophobicity. The chemical structure of CBD contains aromatic rings and an aliphatic side chain, which make it a highly hydrophobic molecule. The hydrophobicity of CBD limits its solubility in water and makes diffusion across aqueous barriers a rate limiting step for diffusion and absorption $[100,101]$.

\section{Topical delivery}

Therapeutic treatments for ocular conditions are frequently administered orally or topically to the eye. Extensive first pass metabolism of CBD prevents a significant amount of drug reaching the eye from oral administration. Therefore, topical administration of CBD is desired.

Developing an ocular topical delivery system is a difficult task. The eye contains sophisticated protective mechanisms and physical barriers to prevent foreign material from entering, which includes the multi-layered cornea and pre-corneal tear film. The alternating lipophilic and hydrophilic nature of the cornea makes ocular drug delivery exceptionally difficult. As a result, less than 5\% of drugs applied topically enter the eye [103-105].

CBD is highly hydrophobic and insoluble in water. Studies applying CBD topically used non-aqueous vehicles for delivery $[39,63,75]$. Previously, CBD was topically delivered to the eye in mineral oil, sesame oil, soybean oil, and a soya oil/water emulsion, Tocrisolve $[39,63,75]$. In one report, CBD delivered in mineral oil produced an IOP-lowering effect whilst the effect is absent in sesame oil [75]. With Tocrisolve as a vehicle, Miller et al. [63] 
demonstrated that a high dose of CBD increases IOP in wildtype mice, but decreases IOP in CB1 knockout mice. This indicates that at large doses CBD produces off-target effects which are detrimental. Since CBD has at least 65 targets [18], off-target effects of CBD at high doses are very likely. These results highlight a critical need for a vehicle with high ocular permeation to administer CBD in a therapeutically relevant dose.

\section{Duration of action}

Another difficulty associated with CBD as an ocular therapeutic is its short duration of action, e.g., in lowering IOP. One report indicated CBD decreased IOP 1-2 hours after topical application to rabbit eyes, and IOP-lowering effects of CBD lasted for up to 5 hours after intravenous administration [75]. In another study, CBD required constant infusion via minipump to induce a decrease in IOP [76]. A short duration of action implies that CBD needs to be applied multiple times throughout the day to maintain therapeutic effects. However, patient compliance will be worsened with frequent dosing. In contrast, greater patient compliance is observed in prescribed medications with once daily dosing [106].

\section{Future directions}

So far, CBD has been studied preclinically for its therapeutic potentials in glaucoma, diabetic retinopathy, and corneal injury. Considering its anti-inflammatory, antioxidant, and neuroprotective properties, in the future it would be worthwhile to explore the potential of CBD in treating other ocular conditions, such as uveitis and age-related macular degeneration.

It is important to elucidate the mechanisms of action of CBD in the eye. As highlighted in this review, there are multiple molecular targets of CBD in the eye. Understanding which targets are responsible for the therapeutic and adverse effects of CBD is critical for its effective and safe use as an ocular therapeutic agent.

Finally, in the future, solving the puzzles of dosing and proper formulation for efficient, prolonged topical delivery will usher CBD forth for numerous potential ocular therapeutic indications.

\section{Acknowledgements}

The authors acknowledge the support of Department of Pharmacology and Toxicology, University of Louisville School of Medicine.

\section{Author Contributions}

AA and MD wrote the initial versions of the review. LS and ZHS edited and finalized the manuscript.

\section{Funding Sources}

While writing this manuscript, AA is supported in part by NIH grant T32 ES011564; MD is supported in part by NIH grant R25 CA134283; LS is supported in part by University of Louisville Integrated Programs in Biomedical Sciences (IPIBS) Fellowship; and ZHS is supported in part by NIH grant EY030186.

\section{Statement of Ethics}

The authors have no ethical conflicts to disclose.

\section{Disclosure Statement}

The authors have no conflicts of interest to declare. 


\section{Cellular Physiology Cell Physiol Biochem 2021;55(S5):1-14 \begin{tabular}{l|l|l}
\cline { 2 - 3 } DOI: 10.33594/000000371 & ( 2021 The Author(s). Published by
\end{tabular} and BIOChemistry Published online: 14 May $2021 \quad$ Cell Physiol Biochem Press GmbH\&Co. KG \\ Aebersold et al.: Cannabidiol Signaling and Therapeutic Potential for the Eye}

\section{References}

1 Brand EJ, Zhao Z: Cannabis in Chinese Medicine: Are Some Traditional Indications Referenced in Ancient Literature Related to Cannabinoids? Front Pharmacol 2017;8:108.

2 Piomelli D: The molecular logic of endocannabinoid signalling. Nat Rev Neurosci 2003;4:873-884.

3 O'Shaughnessy WB, Calcutta MD: New remedy for tetanus and other convulsive disorders. Boston Med Surg J 1840:153-155.

4 Convention USP: Pharmacopoeia of the United States, ed 3. Philadelphia, PA, Lippincott, Grambo \& Company, 1851.

5 Gieringer DH: The Origins of Cannabis Prohibition in California. Contemp Drug Probl1999;26:237-288.

6 Marijuana Tax Act of 1937. URL: https://www.druglibrary.org/schaffer/hemp/taxact/mjtaxact.htm.

7 Controlled Substances Act, 1970. URL: https://www.govinfo.gov/content/pkg/STATUTE-84/pdf/STATUTE84-Pg1236.pdf.

8 Compassionate Use Act of 1996. URL: https://leginfo.legislature.ca.gov/faces/codes_displaySection.xhtml?! awCode=HSC\&sectionNum=11362.5.

9 Agricultural Act of 2014. URL: https://www.congress.gov/bill/113th-congress/house-bill/2642.

10 Agriculture Improvement Act of 2018. URL: https://www.congress.gov/bill/115th-congress/house-bill/2.

11 Turner CE, Elsohly MA, Boeren EG: Constituents of Cannabis sativa L. XVII. A review of the natural constituents. J Nat Prod 1980;43:169-234.

12 ElSohly AM, Gul W: Constituents of Cannabis Sativa; in Pertwee R (ed): Handbook of Cannabis. Oxford, UK, Oxford University Press, 2014.

13 Mudge EM, Murch SJ, Brown PN: Chemometric Analysis of Cannabinoids: Chemotaxonomy and Domestication Syndrome. Sci Rep 2018;8:13090.

14 Adams R, Hunt M, Clark JH: Structure of Cannabidiol, a Product Isolated from the Marihuana Extract of Minnesota Wild Hemp. I. J Am Chem Soc 1940;62:196-200.

15 Mechoulam R, Shvo Y: Hashish. I. The structure of cannabidiol. Tetrahedron 1963;19:2073-2078.

16 Taura F, Morimoto S, Shoyama Y: Purification and characterization of cannabidiolic-acid synthase from Cannabis sativa L.. Biochemical analysis of a novel enzyme that catalyzes the oxidocyclization of cannabigerolic acid to cannabidiolic acid. J Biol Chem 1996;271:17411-17416.

17 Gaoni Y, Mechoulam R: Isolation, Structure, and Partial Synthesis of an Active Constituent of Hashish. J Am Chem Soc 1964;86:1646-1647.

18 Ibeas Bih C, Chen T, Nunn AV, Bazelot M, Dallas M, Whalley BJ: Molecular Targets of Cannabidiol in Neurological Disorders. Neurotherapeutics 2015;12:699-730.

19 FDA: MARINOL (dronabinol): Highlights of Prescribing Information, 2017. URL: https://www.accessdata. fda.gov/drugsatfda_docs/label/2017/018651s029lbl.pdf.

20 FDA: Syndros: Highlights of Prescribing Information, 2017. URL: https://www.accessdata.fda.gov/ drugsatfda_docs/label/2017/205525s003lbl.pdf.

21 FDA: Cesamet (nabilone) Capsules For Oral Administration, 2006. URL: https://www.accessdata.fda.gov/ drugsatfda_docs/label/2006/018677s011lbl.pdf.

22 Badowski ME, Yanful PK: Dronabinol oral solution in the management of anorexia and weight loss in AIDS and cancer. Ther Clin Risk Manag 2018;14:643.

23 FDA: Epidiolex: Highlights of Prescribing Information, 2018. URL: https://www.accessdata.fda.gov/ drugsatfda_docs/label/2018/210365lbl.pdf.

24 FDA: FDA Approves New Indication for Drug Containing an Active Ingredient Derived from Cannabis to Treat Seizures in Rare Genetic Disease, 2020. URL: https://www.fda.gov/news-events/pressannouncements/fda-approves-new-indication-drug-containing-active-ingredient-derived-cannabis-treatseizures-rare\#: :text=Today\%2C\%20the\%20U.S.\%20Food\%20and,year\%20of\%20age\%20and\%20older.

25 Establishment of a New Drug Code for Marihuana Extract, 2016. URL: https://www.federalregister.gov/ documents/2016/12/14/2016-29941/establishment-of-a-new-drug-code-for-marihuana-extract.

26 Barnes MP: Sativex®: clinical efficacy and tolerability in the treatment of symptoms of multiple sclerosis and neuropathic pain. Expert Opin Pharmacother 2006;7:607-615.

27 Atalay S, Jarocka-Karpowicz I, Skrzydlewska E: Antioxidative and Anti-Inflammatory Properties of Cannabidiol. Antioxidants (Basel) 2019;9:21. 


\section{Cellular Physiology Cell Physiol Biochem 2021;55(S5):1-14 \begin{tabular}{ll|l} 
and Biochemistry & $\begin{array}{l}\text { DOl: 10.33594/000000371 } \\
\text { Published online: 14 May 2021 }\end{array}$ & $\begin{array}{l}\text { O } 2021 \text { The Author(s). Published by } \\
\text { Cell Physiol Biochem Press GmbH\&Co. KG }\end{array}$ \\
\cline { 2 - 3 } &
\end{tabular} \\ Aebersold et al.: Cannabidiol Signaling and Therapeutic Potential for the Eye}

28 Hampson AJ, Grimaldi M, Lolic M, Wink D, Rosenthal R, Axelrod J: Neuroprotective antioxidants from marijuana. Ann N Y Acad Sci 2000;899:274-282.

29 Paolino MC, Ferretti A, Papetti L, Villa MP, Parisi P: Cannabidiol as potential treatment in refractory pediatric epilepsy. Expert Rev Neurother 2016;16:17-21.

30 Leo A, Russo E, Elia M: Cannabidiol and epilepsy: Rationale and therapeutic potential. Pharmacol Res 2016;107:85-92.

31 Campos AC, Fogaça MV, Sonego AB, Guimarães FS: Cannabidiol, neuroprotection and neuropsychiatric disorders. Pharmacol Res 2016;112:119-127.

32 Kis B, Ifrim FC, Buda V, Avram S, Pavel IZ, Antal D, Paunescu V, Dehelean CA, Ardelean F, Diaconeasa Z, Soica C, Danciu C: Cannabidiol-from Plant to Human Body: A Promising Bioactive Molecule with Multi-Target Effects in Cancer. Int J Mol Sci 2019;20

33 Stanley CP, Hind WH, O'Sullivan SE: Is the cardiovascular system a therapeutic target for cannabidiol? $\mathrm{Br}$ J Clin Pharmacol 2013;75:313-322.

34 Passani A, Posarelli C, Sframeli AT, Perciballi L, Pellegrini M, Guidi G, Figus M: Cannabinoids in Glaucoma Patients: The Never-Ending Story. J Clin Med 2020;9:3978.

35 Pena J, Jimenez C, Schmidt J: Do cannabinoids play a role in the control of glaucoma? Medwave 2018;18:e7144.

36 Schwitzer T, Schwan R, Angioi-Duprez K, Giersch A, Laprevote V: The Endocannabinoid System in the Retina: From Physiology to Practical and Therapeutic Applications. Neural Plast 2016;2016:2916732.

37 Kokona D, Georgiou PC, Kounenidakis M, Kiagiadaki F, Thermos K: Endogenous and Synthetic Cannabinoids as Therapeutics in Retinal Disease. Neural Plast 2016;2016:8373020.

38 Belmonte C, Acosta MC, Merayo-Lloves J, Gallar J: What Causes Eye Pain? Curr Ophthalmol Rep 2015;3:111121.

39 Thapa D, Cairns EA, Szczesniak AM, Toguri JT, Caldwell MD, Kelly MEM: The Cannabinoids Delta(8) THC, CBD, and HU-308 Act via Distinct Receptors to Reduce Corneal Pain and Inflammation. Cannabis Cannabinoid Res 2018;3:11-20.

40 Rashid K, Akhtar-Schaefer I, Langmann T: Microglia in Retinal Degeneration. Front Immunol 2019;10:1975.

41 Wang AL, Albert C, Lau LT, Lee C, Tso MO: Minocycline inhibits LPS-induced retinal microglia activation. Neurochem Int 2005;47:152-158.

42 Hasko G, Pacher P, Vizi ES, Illes P: Adenosine receptor signaling in the brain immune system. Trends Pharmacol Sci 2005;26:511-516.

43 Noji T, Takayama M, Mizutani M, Okamura Y, Takai H, Karasawa A, Kusaka H: KF24345, an adenosine uptake inhibitor, suppresses lipopolysaccharide-induced tumor necrosis factor-alpha production and leukopenia via endogenous adenosine in mice. J Pharmacol Exp Ther 2002;300:200-205.

44 Liou GI, Auchampach JA, Hillard CJ, Zhu G, Yousufzai B, Mian S, Khan S, Khalifa Y: Mediation of cannabidiol anti-inflammation in the retina by equilibrative nucleoside transporter and A2A adenosine receptor. Invest Ophthalmol Vis Sci 2008;49:5526-5531.

45 Dreyer EB: A proposed role for excitotoxicity in glaucoma. J Glaucoma 1998;7:62-67.

46 Dreyer EB, Zurakowski D, Schumer RA, Podos SM, Lipton SA: Elevated glutamate levels in the vitreous body of humans and monkeys with glaucoma. Arch Ophthalmol 1996;114:299-305.

47 Choi DW: Glutamate neurotoxicity and diseases of the nervous system. Neuron 1988;1:623-634.

48 Waxman EA, Lynch DR: N-methyl-D-aspartate receptor subtypes: multiple roles in excitotoxicity and neurological disease. Neuroscientist 2005;11:37-49.

49 Coyle JT, Puttfarcken P: Oxidative stress, glutamate, and neurodegenerative disorders. Science 1993;262:689-695.

50 Misko TP, Highkin MK, Veenhuizen AW, Manning PT, Stern MK, Currie MG, Salvemini D: Characterization of the cytoprotective action of peroxynitrite decomposition catalysts. J Biol Chem 1998;273:15646-15653.

51 El-Remessy AB, Khalil IE, Matragoon S, Abou-Mohamed G, Tsai NJ, Roon P, Caldwell RB, Caldwell RW, Green K, Liou GI: Neuroprotective effect of (-)Delta9-tetrahydrocannabinol and cannabidiol in N-methyl-Daspartate-induced retinal neurotoxicity: involvement of peroxynitrite. Am J Pathol 2003;163:1997-2008.

52 Li C, Miao X, Li F, Wang S, Liu Q, Wang Y, Sun J: Oxidative Stress-Related Mechanisms and Antioxidant Therapy in Diabetic Retinopathy. Oxid Med Cell Longev 2017;2017:9702820.

53 Aiello LP, Wong JS: Role of vascular endothelial growth factor in diabetic vascular complications. Kidney Int Suppl 2000;77:S113-119. 


\section{Cellular Physiology Cell Physiol Biochem 2021;55(S5):1-14 \begin{tabular}{l|l|l} 
and Biol: 10.33594/000000371 & (c)21 The Author(s). Published by
\end{tabular} and BIOChemistry Published online: 14 May $2021 \quad$ Cell Physiol Biochem Press GmbH\&Co. KG \\ Aebersold et al.: Cannabidiol Signaling and Therapeutic Potential for the Eye}

54 Kamiuchi K, Hasegawa G, Obayashi H, Kitamura A, Ishii M, Yano M, Kanatsuna T, Yoshikawa T, Nakamura N: Intercellular adhesion molecule-1 (ICAM-1) polymorphism is associated with diabetic retinopathy in Type 2 diabetes mellitus. Diabet Med 2002;19:371-376.

55 Semeraro F, Cancarini A, dell'Omo R, Rezzola S, Romano MR, Costagliola C: Diabetic Retinopathy: Vascular and Inflammatory Disease. J Diabetes Res 2015;2015:582060.

56 Igarashi M, Wakasaki H, Takahara N, Ishii H, Jiang ZY, Yamauchi T, Kuboki K, Meier M, Rhodes CJ, King GL: Glucose or diabetes activates p38 mitogen-activated protein kinase via different pathways. J Clin Invest 1999;103:185-195.

57 Purves T, Middlemas A, Agthong S, Jude EB, Boulton AJ, Fernyhough P, Tomlinson DR: A role for mitogenactivated protein kinases in the etiology of diabetic neuropathy. FASEB J 2001;15:2508-2514.

58 El-Remessy AB, Al-Shabrawey M, Khalifa Y, Tsai NT, Caldwell RB, Liou GI: Neuroprotective and blood-retinal barrier-preserving effects of cannabidiol in experimental diabetes. Am J Pathol 2006;168:235-244.

59 Phu J, Agar A, Wang H, Masselos K, Kalloniatis M: Management of open-angle glaucoma by primary eye-care practitioners: toward a personalised medicine approach. Clin Exp Optom 2021;104:367-384.

60 Jonas JB, Aung T, Bourne RR, Bron AM, Ritch R, Panda-Jonas S: Glaucoma. Lancet 2017;390:2183-2193.

61 Shalaby WS, Shankar V, Razeghinejad R, Katz LJ: Current and new pharmacotherapeutic approaches for glaucoma. Expert Opin Pharmacother 2020;21:2027-2040.

62 Lu LJ, Tsai JC, Liu J: Focus: Drug Development: Novel Pharmacologic Candidates for Treatment of Primary Open-Angle Glaucoma. Yale J Biol med 2017;90:111-118.

63 Miller S, Daily L, Leishman E, Bradshaw H, Straiker A: Delta9-Tetrahydrocannabinol and Cannabidiol Differentially Regulate Intraocular Pressure. Invest Ophthalmol Vis Sci 2018;59:5904-5911.

64 Tomida I, Azuara-Blanco A, House H, Flint M, Pertwee RG, Robson PJ: Effect of sublingual application of cannabinoids on intraocular pressure: a pilot study. J Glaucoma 2006;15:349-353.

65 Crawford WJ, Merritt JC: Effects of tetrahydrocannabinol on arterial and intraocular hypertension. Int J Clin Pharmacol Biopharm 1979;17:191-196.

66 Cooler P, Gregg JM: Effect of delta-9-tetrahydrocannabinol on intraocular pressure in humans. South Med J 1977;70:951-954.

67 Colasanti BK, Powell SR, Craig CR: Intraocular pressure, ocular toxicity and neurotoxicity after administration of delta 9-tetrahydrocannabinol or cannabichromene. Exp Eye Res 1984;38:63-71.

68 Fischer KM, Ward DA, Hendrix DV: Effects of a topically applied 2\% delta-9-tetrahydrocannabinol ophthalmic solution on intraocular pressure and aqueous humor flow rate in clinically normal dogs. Am J Vet Res 2013;74:275-280.

69 Purnell WD, Gregg JM: Delta(9)-tetrahydrocannabinol,, euphoria and intraocular pressure in man. Ann Ophthalmol 1975;7:921-923.

70 Waller CW, Benigni DA, Harland E, Bedford JA, Murphy JC, ElSohly MA: Cannabinoids in Glaucoma III: The Effects of Different Cannabinoids on Intraocular Pressure in the Monkey, in Agurell S, et al (eds): The Cannabinoids: Chemical, Pharmacologic, and Therapeutic Aspects 1984, pp 871-880.

71 Liu JH, Dacus AC: Central nervous system and peripheral mechanisms in ocular hypotensive effect of cannabinoids. Arch Ophthalmol 1987;105:245-248.

72 Green K, Symonds CM, Oliver NW, Elijah RD: Intraocular pressure following systemic administration of cannabinoids. Curr Eye Res 1982;2:247-253.

73 ElSohly MA, Harland EC, Benigni DA, Waller CW: Cannabinoids in glaucoma II: the effect of different cannabinoids on intraocular pressure of the rabbit. Curr Eye Res 1984;3:841-850.

74 Perez-reyes M, Wagner D, Wall ME, Davis KH: Intravenous administration of cannabinoids and intraocular pressure, in: Braude, MC and Szara, S (eds): The Pharmacology of Marihmana, Raven, New York, 1976, pp. 829-832.

75 Green K, Wynn H, Bowman KA: A comparison of topical cannabinoids on intraocular pressure. Exp Eye Res 1978;27:239-246.

76 Colasanti BK, Brown RE, Craig CR: Ocular hypotension, ocular toxicity, and neurotoxicity in response to marihuana extract and cannabidiol. Gen Pharmacol 1984;15:479-484.

77 Shelton B: CBD Oil May Worsen Glaucoma. American Academy of Ophthalmology, 2019. URL: https://www. aao.org/eye-health/news/cbd-oil-may-worsen-glaucoma.

78 Russo EB, Burnett A, Hall B, Parker KK: Agonistic properties of cannabidiol at 5-HT1a receptors. Neurochem Res 2005;30:1037-1043. 


\section{Cellular Physiology Cell Physiol Biochem 2021;55(S5):1-14

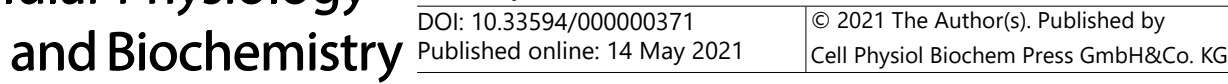 \\ Aebersold et al.: Cannabidiol Signaling and Therapeutic Potential for the Eye}

79 De Gregorio D, McLaughlin RJ, Posa L, Ochoa-Sanchez R, Enns J, Lopez-Canul M, Aboud M, Maione S, Comai S, Gobbi G: Cannabidiol modulates serotonergic transmission and reverses both allodynia and anxiety-like behavior in a model of neuropathic pain. Pain 2019;160:136-150.

80 Pandolfo P, Silveirinha V, dos Santos-Rodrigues A, Venance L, Ledent C, Takahashi RN, Cunha RA, Kofalvi A: Cannabinoids inhibit the synaptic uptake of adenosine and dopamine in the rat and mouse striatum. Eur J Pharmacol 2011;655:38-45.

81 Carrier EJ, Auchampach JA, Hillard CJ: Inhibition of an equilibrative nucleoside transporter by cannabidiol: a mechanism of cannabinoid immunosuppression. Proc Natl Acad Sci U S A 2006;103:7895-7900.

82 Laprairie R, Bagher A, Kelly M, Denovan-Wright E: Cannabidiol is a negative allosteric modulator of the cannabinoid CB1 receptor. Br J Pharmacol 2015;172:4790-4805.

83 Straiker AJ, Maguire G, Mackie K, Lindsey J: Localization of cannabinoid CB1 receptors in the human anterior eye and retina. Invest Ophthalmol Vis Sci 1999;40:2442-2448.

84 Stamer WD, Golightly SF, Hosohata Y, Ryan EP, Porter AC, Varga E, Noecker RJ, Felder CC, Yamamura HI: Cannabinoid $\mathrm{CB}(1)$ receptor expression, activation and detection of endogenous ligand in trabecular meshwork and ciliary process tissues. Eur J Pharmacol 2001;431:277-286.

85 Kohno M, Hasegawa H, Inoue A, Muraoka M, Miyazaki T, Oka K, Yasukawa M: Identification of $\mathrm{N}$-arachidonylglycine as the endogenous ligand for orphan G-protein-coupled receptor GPR18. Biochem Biophys Res Commun 2006;347:827-832.

86 McHugh D, Page J, Dunn E, Bradshaw HB: Delta(9) -Tetrahydrocannabinol and N-arachidonyl glycine are full agonists at GPR18 receptors and induce migration in human endometrial HEC-1B cells. Br J Pharmacol 2012;165:2414-2424.

87 Console-Bram L, Brailoiu E, Brailoiu GC, Sharir H, Abood ME: Activation of GPR18 by cannabinoid compounds: a tale of biased agonism. Br J Pharmacol 2014;171:3908-3917.

88 Caldwell MD, Hu SS, Viswanathan S, Bradshaw H, Kelly ME, Straiker A: A GPR18-based signalling system regulates IOP in murine eye. Br J Pharmacol 2013;169:834-843.

89 MacIntyre J, Dong A, Straiker A, Zhu J, Howlett SE, Bagher A, Denovan-Wright E, Yu DY, Kelly ME: Cannabinoid and lipid-mediated vasorelaxation in retinal microvasculature. Eur J Pharmacol 2014;735:105-114.

90 Alhouayek M, Masquelier J, Muccioli GG: Lysophosphatidylinositols, from Cell Membrane Constituents to GPR55 Ligands. Trends Pharmacol Sci 2018;39:586-604.

91 Morales P, Jagerovic N: Advances Towards The Discovery of GPR55 Ligands. Curr Med Chem 2016;23:20872100 .

92 Cherif H, Argaw A, Cecyre B, Bouchard A, Gagnon J, Javadi P, Desgent S, Mackie K, Bouchard JF: Role of GPR55 during Axon Growth and Target Innervation. eNeuro 2015; DOI: 10.1523/ENEURO.0011-15.2015.

93 Montell C: The TRP superfamily of cation channels. Sci STKE 2005;2005:re3.

94 Muller C, Morales P, Reggio PH: Cannabinoid Ligands Targeting TRP Channels. Front Mol Neurosci 2018;11:487.

95 De Petrocellis L, Orlando P, Moriello AS, Aviello G, Stott C, Izzo AA, Di Marzo V: Cannabinoid actions at TRPV channels: effects on TRPV3 and TRPV4 and their potential relevance to gastrointestinal inflammation. Acta Physiol (Oxf) 2012;204:255-266.

96 Hung CY, Tan CH: TRP Channels in Nociception and Pathological Pain. Adv Exp Med Biol 2018;1099:13-27.

97 Levine JD, Alessandri-Haber N: TRP channels: targets for the relief of pain. Biochim Biophys Acta 2007;1772:989-1003.

98 Barro-Soria R, Stindl J, Muller C, Foeckler R, Todorov V, Castrop H, Strauss O: Angiotensin-2-mediated Ca2+ signaling in the retinal pigment epithelium: role of angiotensin-receptor-associated-protein and TRPV2 channel. PLoS One 2012; 7:e49624.

99 Reichhart N, Keckeis S, Fried F, Fels G, Strauss O: Regulation of surface expression of TRPV2 channels in the retinal pigment epithelium. Graefes Arch Clin Exp Ophthalmol 2015;253:865-874.

100 Gottschling S, Ayonrinde 0, Bhaskar A, Blockman M, D’Agnone O, Schecter D, Suarez Rodriguez LD, Yafai S, Cyr C: Safety Considerations in Cannabinoid-Based Medicine. Int J Gen Med 2020;13:1317-1333.

101 Britch SC, Babalonis S, Walsh SL: Cannabidiol: pharmacology and therapeutic targets. Psychopharmacology (Berl) 2020;238:9-28. 


\section{Cellular Physiology Cell Physiol Biochem 2021;55(S5):1-14}

\begin{tabular}{ll|l} 
and Biochemistry & $\begin{array}{l}\text { DOl: 10.33594/000000371 } \\
\text { Published online: 14 May } 2021\end{array}$ & $\begin{array}{l}\text { ( 2021 The Author(s). Published by } \\
\text { Cell Physiol Biochem Press GmbH\&Co. KG }\end{array}$ \\
\cline { 2 - 3 } &
\end{tabular}

Aebersold et al.: Cannabidiol Signaling and Therapeutic Potential for the Eye

102 Chesney E, Oliver D, Green A, Sovi S, Wilson J, Englund A, Freeman TP, McGuire P: Adverse effects of cannabidiol: a systematic review and meta-analysis of randomized clinical trials. Neuropsychopharmacology 2020;45:1799-1806.

103 Souza JG, Dias K, Pereira TA, Bernardi DS, Lopez RF: Topical delivery of ocular therapeutics: carrier systems and physical methods. J Pharm Pharmacol 2014;66:507-530.

104 Yellepeddi VK, Palakurthi S: Recent Advances in Topical Ocular Drug Delivery. J Ocul Pharmacol Ther 2016;32:67-82.

105 Tomida I, Pertwee RG, Azuara-Blanco A: Cannabinoids and glaucoma. Br J Ophthalmol 2004;88:708-713.

106 Richter A, Anton SF, Koch P, Dennett SL: The impact of reducing dose frequency on health outcomes. Clin Ther 2003;25:2307-2335; discussion 2306. 